\title{
A ordem cristã no governo dos escravos: normas para a cristianização e tratamento dos escravos no Brasil colonial (1697-1759)
}

\author{
Brunno Hoffmann Velloso da Silva \\ Orientador: Doutor Eurico Antônio González Cursino dos \\ Santos \\ Dissertação de Mestrado \\ Data da defesa: 30.07.2011
}

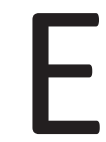

sta dissertação trata de um pequeno conjunto de textos escritos no Brasil colonial, entre finais do século XVII e meados do XVIII, que procuravam regular a escravidão negra com preceitos cristãos. Buscou-se, no curso da investigação, compreender em que consistia o conjunto dessas regras e o que prescreviam a senhores e escravos. Notou-se a constante preocupação dos autores dessas obras com o tratamento dado pelos senhores a seus escravos no que dizia respeito à alimentação, vestimenta, saúde, catequização, castigos, entre outros temas recorrentes em todos os textos que constituem o objeto desta pesquisa. Assim, esses escritos, ao tratarem de questões relacionadas à vida prática e cotidiana dos escravos, tomavam, por vezes, a forma de um manual ou um compêndio que reunia métodos e regras cristãs para escravizar o negro. Com o intuito de contextualizar historicamente a argumentação apresentada nos livros que serviram de objeto de estudo desta investigação, uma parte da pesquisa dedicou-se a rever alguns antecedentes dessas obras. Além disso, procurou-se conhecer um pouco da história de seus autores e da publicação dessas obras, num esforço de identificar uma origem intelectual e moral das ideias e valores propagados nesses textos que se dedicaram a ensinar aos senhores um modo cristão de escravizar. Como estratégia analítica, o conteúdo de tais normas foi organizado sob grandes temáticas que se mostraram de interesse comum a todos os autores dos livros aqui estudados. A partir disso, esta pesquisa concentrou-se em apresentar uma descrição sistemática dessas regras e prescrições de modo a compreender parte do plano religioso que se traçou para a escravidão negra nas terras brasileiras.

Palavras-chave: Escravidão, Religião, Brasil, Século XVIII, Tratamento dos Escravos. 